\title{
The Implication of Sky Quality Meter Technology in Observing the Dawn To Determine Subh Prayer Time
}

\author{
$1^{\text {st }}$ Maskufa $^{1}, 2^{\text {nd }}$ D.R. Munazat ${ }^{1}, 3^{\text {rd }}$ Adi Damanhuri ${ }^{1}, 4^{\text {th }}$ Ahmad Bisyri Abd. Shomad ${ }^{1}$ \\ \{maskufa@uinjkt.ac.id ${ }^{1}$, adidamanhuri@uhamka.ac.id ${ }^{1}$, bisyri.shomad@uinjkt.ac.id ${ }^{1}$ \} \\ UIN Syarif Hidayatullah, Faculty of Law and Syaria Jakarta, Indonesia ${ }^{1}$
}

\begin{abstract}
The Subh time specified in the prayer schedule has been considered as early as 20 to 30 minutes, whereas prayer must be done on time. This study aims to verify the phenomenon of dawn shadiq (astronomical twilight) as a mark of dawn time. The research was carried out by observation method using Sky Quality Meter technology and the results will be analyzed with the approach of ushul fiqh science, astronomy, and mathematics. The approach to the science of ushul fiqh is to analyze the normative aspects, the approach of astronomy is to analyze the phenomenon of dawn, and the approach of mathematics to analyze the results of dawn observations with Sky Quality Meter. The results of the study showed that at dawn Shadiq can be observed factually at a depression angle of $15^{\circ}$ to $18^{\circ}$ below the equivalent horizon of 60 to 72 minutes before sunrise. The magnitude of the depression angle is different from the determination of the Ministry of Religion of the Republic of Indonesia and Islamic Organizations that is equal to $20^{\circ}$ below the horizon equivalent to 80 minutes before sunrise. The implication of the findings of this study is the shift of dawn time, imsak time and the start time of fasting 8 to 20 minutes from the time specified in the prayer time schedule.
\end{abstract}

Keywords: Dawn sky, Subh prayer time, SQM technology

\section{Introduction}

The critique on the early determination of Subh prayer time as being too early has been around since 2010 in an article published in Qiblati magazine titled "Salah Kaprah Waktu Subuh" (the misunderstanding of Subh prayer time) written by Syaikh Mamduh Farhan alBukhairi [1]. This article sparks many questions in the society regarding the determination of Subh prayer time. Before, many Muslims in society already agreed that Subh prayer time as it was thought as completely finalized without any doubt and has been listed in the perpetual salat timetable as a guide for Muslim on when to perform their daily prayers.

Susiknan Azhari said that before Syaikh Mamduh Farhan al-Buhairi wrote about the phenomenon of dawn that is being used in Indonesia [2], Hanafi S. Djamari has written an article titled "Menelaah Kembali Awal Shalat Subuh" (examining the starting time of Subh prayer) and as published in the newspaper Republika in May 2, 1999. In his article, Hanafi urged to re-examine the concept of zenith distance of sun to determine Subh prayer time. According to him, the relevant zenith for Subh prayer time is when the solar elevation angle is around $18^{\circ}$ [3]. However, many Muslims are still being unresponsive of the concept he presented at that time. 
Many parties reacted to the concept presented in Qiblati magazine in 2010 about the correction of Subh prayer time. Indonesian government represented by the Director for Islamic Religious Affairs and Syariah Development of the Ministry of Religious Affairs, Rohadi Abdul Fatah stated that the Subh prayer time determined by the government, has been already verified so that the Muslim society didn't have to be restless [4]. The determination of Subh prayer time refer to the calculation result by te Indonesian Hisab and Rukyat Body with the member consisting of the delegation of Islamic organization and experts in cosmography and astronomy so that their calculation is without a doubt a valid one. This view is also supported by one of the biggest Islamic organizations in Indonesia, Muhammadiyah. The vice secretary of Majelis Tarjih Muhammadiyah, Fatah Wibisono said that Subh prayer time is already correct which is when the solar elevation angle is in $20^{\circ}$ below the horizon. Wibisono further asserted, "Muhammadiyah didn't have any differences in determining Subh prayer time from what has been calculated by the Indnesian Hisab and Rukyat Body or the Indonesian government. So there is no need to revise the already calculated Subh prayer schedule." His reaction reassured the Muslim communities and they viewed this as a finalized argument in the calculation of Subh prayer time [5].

However, the discourse about Subh prayer time reappeared again in 2017 in the national seminar, focusing on the subject of "Evaluasi Awal Waktu Shalat Subuh Menurut Sains dan Fikih" (the evaluation of Subh prayer time according to science and fiqh) initiated by the Islamic Science Reseach Network (ISRN), Universitas Muhammadiyah Prof Dr Hamka (UHAMKA) [6]. Tono Saksono stated that scientifically, it has been observed that it our Subh prayer time is indeed around 20-30 minutes too early. Saksono stated that,"The already agreed time of the dawn sky that refer to the solar elevation angle of $20^{\circ}$ below the horizon or equal to 80 minutes before sunrise has been observed to be too early, as the observation shows that the dawn phenomenon as an indicator for Subh prayer time has only started when the solar elevation angle is around $11^{\circ}$ to $15^{\circ}$ below the horizon or equal to 44 to 69 minutes before the sunrise."

The head of the National Institute of Aeronautics and Space (LAPAN), Prof Dr Thomas Djamaluddin in the same seminar also said that it is already time to revised the usage of the standardized angle of $20^{\circ}$ below the horizon, however, the observation needs to be done from a location where there is a minimal atmospheric disturbance to prevent the distortion of the result [7]. This finding was positiviely welcomed by the vice head of Lembaga Falakiyah Nahdlatul Ulama (LFNU), Sirril Wafa. According to Wafa (2017), NU is ready to welcome the change and to initiate research cooperation in astronomy between NU, Muhammadiyah, MUI, Lapan, and others.

The validity in determining Subh prayer time is related to many questions concerning fiqh such as when is the time to start the Subh prayer, the beginning and the end of imsak, and the time to start fasting. These questions can only be answered if the Subh prayer time has been determined. Based on that, there is a necessity to do a research about Subh prayer time that synergized how the Fajr Shadiq or the true dawn is defined in both the Islamic syar'i and scientific aspects. Furthermore, with the invention in the field of optics in the form of sky detector technology or Sky Quality Meter (SQM), the research can be optimized in order to gain the best solution in determining the Subh prayer time. This research was supported by the principles of fiqh that the rule can change according to the difference in time, place, and recent conditions.

\section{The Dawn Sky Phenomenon As A Sign For Subh Prayer Time}


Salat is one of the main act of worship (ibadah) in Islam. Thus, according to the principle of Ushûl, "al-ashlu fí al-'ibâdah al-buthlân hatta yaqûma al-dalîl 'alâ al-'amr" that the initial tenet of ibadah is prohibited unless there is a proof that the ibadah is according to what had been taught by Allah and the Prophet [8]. As-Shatibi stated that ibadah is ta 'abbudî or taken for granted and the practice of ibadah is a form of faith, obedience, and submission to the God [9]. Ibadah can only be done by closely following the set rule and steadying the heart to always remember about Him so that the person can feel His presence within. Thus, in practicing salat, be it related to the obligatory condition (syarat), the pillars (rukun), or the essential acts of salat need to be based on normative aspects that is written in the Quran verse or in the hadith of the Prophet Muhammad SAW.

One of the obligatory condition of salat in the fiqh literature is ascertaining the arrival of stated times for prayer [10]. The knowledge about the arrival time of prayer shows that salat needs to be performed within the correct appointed time. This is in accordance to Quran Surah An-Nisa verse 103, "Indeed, performing prayers is a duty on the believers at the appointed times". The word mauqûta in this verse, according to Muhammad Quraish Shihab is an ever unchanging obligatory [11]. Muhammad Ali al-Sais and Muhammad Ali al-Shabuni said that the meaning behind mauqûta is an obligation that is tied with a specified time and it is forbidden to exceed that [12], [13]. This verse is a mujmal verse (containing word or statement whose meaning is not clear) and the explanation can be found in the hadith of the Prophet Muhammad SAW. Ibnu Katsir quoted the perspective of Ibnu Abbas and Ibnu Mas'ud said that to perform the worship prayer of salat there is a prescribed appointed time like performing the Hajj [14].

The arrival of stated time for Subh prayer started after the dawn and ended when the sun rises. The dawn is marked by the the disappearance or the dimming of the stars. Quran verse Surah At-Thûr verse 49 call the phenomenon as "idbâr al-nujûm" which ended as stated in Quran Surah Qaaf verse 39 which is at "thulu "al-syams" or the rising of the sun. The explanation on the arrival of stated time for Subh prayer is described within a few hadith of the Prophet Muhammad SAW, some of them are: (1) Hadith narrated by Abdullah ibn Amar in Sahih Muslim (hadith 966), The time for Subh prayer is from the coming of dawn until before the sun rises; (2) Hadith narrated by Jabir ibn Abdullah in Sunan al-Nasa'i (hadith 510), the arrival time of Subh prayer is when the dawn has spread and the morning has come, Jibrl is coming and the star is at its brightest; (3) Hadith narrated by Ibn Abbas in Sunan al-Tirmidzi (hadith 138), the arrival time of Subh prayer is when the dawn has come and the food becomes forbidden for those who do fasting which is when the sun started to spread its light around. These three hadith asserted the importance of the coming of dawn as the sign for the arrival time of Subh prayer.

The entity that is known as dawn as the sign for the arrival time of Subh prayer refers to the second dawn or better known as fajr shadiq (true dawn), while the first dawn is known as fajr kadzib (false dawn) which resembles a wolf's tail (kadzanbi al-sirhân). Different from fajr shadiq which is heavily related to many worship rituals, fajr kadzib doesn't have any implications toward the Islamic worship ritual. The existence of two dawn has been asserted in the hadith, "From Ibn Abbas RA, he said: Rasulullah SAW has said: The dawn is of two types: As for the first, it doesn't prevent eating nor does it permit prayer (Subh prayer). As for the other, it prohibits eating (for the fasting person) and allows the prayer". This hadith is narrated by Ibn Khuzaimah and Hakim and passed down by both of them. And in Hakim from the hadith Jabir is also like that but he added about the dawn which prohibits eating that "spreads across and covers the horizon", and the other dawn which doesn't prohibit anything that it "is like the tail of a wolf (kadzanbi al-sirhân)". 
Ibnu Hajar al-Asqalani the meaning behind the word mustathîlan is elongated and lie horizontally, while al-sirhân al-dzanbi is the raising of the lights spreading in the horizon to the sky vertically so that it looks like a tail of a wolf [15]. Hasan explained more about the two types of dawn, stating that fajr shadiq is a white mark at the edge of the eastern sky spreads across and covers the horizon accompanying the end of the night [16]. That is the true dawn where a Muslim is prohibited to eat and drink but is allowed to perform Subh prayer. Meanwhile, fajr kadzib is a white mark in the eastern sky which spread vertically (upwards) like a tail of wolf. This dawn comes before the true dawn where the night is still around, thus, this is the lying dawn in which it doesn't prevent eating or drink but prohibits the Subh prayer because it hasn't entered the time. Therefore, fajr shadiq is related to the rules of syara ' such as the starting time to do fasting, Subh prayer, and the end of the time for Isha prayer while fajr $k a d z i b$ is not related to the rules of syara'. The characteristics of these two types of dawn mentioned within the hadith of the Prophet is necessary to be observed factually both in the perspective of syar'i and science so that the prayer can be performed in the appointed time.

\section{The Observation Of Dawn Using The Sky Quality Meter TechnologY}

The determination of Subh prayer time started with the phenomenon of the dawn, which is the true dawn or fajr shadiq and not the lying dawn or fajr kadzib. Fajr kadzib is a white mark vertically resembling a wolf's tail or in the astronomical literature is known as zodiacal light. As for fajr shadiq, it is a white mark that spread across horizontally accompanying the end of the night or in the astronomical literature is known as astronomical twilight.

In astronomy, the dawn sky phenomenon or morning twilight was divided into three which is astronomical twilight, nautical twilight, and civil twilight [17]. Astronomical twilight is defined as the end of the night when the lights from the stars started to dim because of the lights spreading from the sun. Usually defined by the curvature of the light, astronomical twilight comes when the sun is at around $18^{\circ}$ below the horizon. Nautical twilight is a where the dawn becomes visible for the sailors, happening at around $12^{\circ}$ below the horizon. Civil twilight is when the dawn is started to be reflected in everything around us which happens at around $6^{\circ}$. These three twilights can be seen in Figure 1.

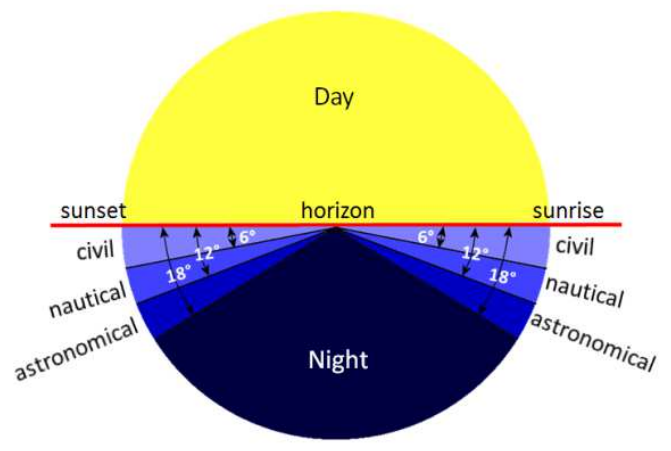

Figure 1. Definition of Twilight, credit: www.weather.gov

The phenomenon of fajr shadiq or astronomical twilight marked by the burst of light in the eastern horizon is relative to the position of the sun. This phenomenon happened because of the 
scattering of the sunlight by the particles in the atmosphere surrounding the earth. In Quran Surah Al-Baqarah verse 187, it was stated as "until the white thread of dawn becomes distinct to you from the black thread (of night)". As for the exact solar elevation for this fajr shadiq, there are many differing opinions. According to the expert of cosmography in Indonesia such as KH.Zubair Umar al-Jailani and Abdur Rachim, the elevation was around $-18^{\circ}$ to $-20^{\circ}$ [18]. The Ministry for Religious Affairs used the elevation at $-20^{\circ}$ based on the reasoning that the sensitivity of the eye is higher during this time because of the transition from darkness to light. However, in the recent development regarding to the solar elevation, fajr shadiq happened at around $11^{\circ}$ to $15^{\circ}$ below the horizon [19]. When converted into minute, the difference can reach 20 to 30 minutes from the already established Subh prayer time.

Nowadays, the research into the dawn sky phenomenon as the sign of the arrival of the stated time for Subh prayer can be done with the help of Sky Quality Meter (SQM). SQM is a modern photometer device that can be used to detect the brightness of the night sky so it can be very practical to observe and detect the coming of fajr shadiq. Beside that, SQM is also used for several reasearch such as selection of astronomical sites [20], Effects of cloud amount on the night sky brightness [21], survey of light pollution [22]-[25], research of moon crescent sighting [26], research of bird living near airport [27], to research of prayer time evaluation [6]. This research used the SQM model SQM-LU-DL (SQM Lens USB-Data Logger) to observe the dawn. The SQM-LU-DL can automatically record and read the data of the observation using USB connection with or without the help of a computer. The observation using this SQM resulted in the data of the night sky brightness in the scale of magnitudes per arc second square (MPSAS).

This observation of the dawn sky phenomenon is using SQM model SQM-LU-DL produced by Unihedron with the serial number AL0316VH and firmware version 4.6.56. During the observation, the light censor will capture and record the situation in the observation location which will be processed within the micro-controller. Although equipped with data logger, the observation was done with the help of a computer connected to the SQM-LU-DL by using USB cable. The data from the observation will then be read by using Unihedron Device Manager (UDM) version 1.0.0.157.

The observation was done in Depok and Yogyakarta with geographical data and the date of observation logged in the table 1.

Table 1. Location and Date of Observation

\begin{tabular}{|c|c|c|c|}
\hline Location & Latitude & Longitude & Date \\
\hline Kota Depok & $\begin{array}{l}-6.392968 \\
\text { S }\end{array}$ & $\begin{array}{l}106.761872 \\
\text { E }\end{array}$ & $\begin{array}{l}\text { May } 11 \& 13, \\
2018\end{array}$ \\
\hline $\begin{array}{l}\text { Krakal } \\
\text { Beach, } \\
\text { Yogyakarta }\end{array}$ & $-8.148838 \mathrm{~S}$ & $\begin{array}{l}110.595726 \\
\mathrm{E}\end{array}$ & July 21,2018 \\
\hline $\begin{array}{l}\text { Panguk } \\
\text { Hills, } \\
\text { Yogyakarta }\end{array}$ & $-7.959344 \mathrm{~S}$ & $\begin{array}{l}110.441156 \\
\text { E }\end{array}$ & July 22,2018 \\
\hline
\end{tabular}

The observation in several location mentioned in table 1 was done in varied time, between midnight until the sunrise. The direction of SQM was also varied to prevent the lighting effect from the moon. The resulting data from SQM was then compared to the solar position data from NOAA. The data from SQM is in the form of ASCII in the format of .txt file. To process this data further, it needs to be converted into the.xsl file format. Afterwards, using Ms Excel, the data can be shown as a graphical chart in Figure 2. 


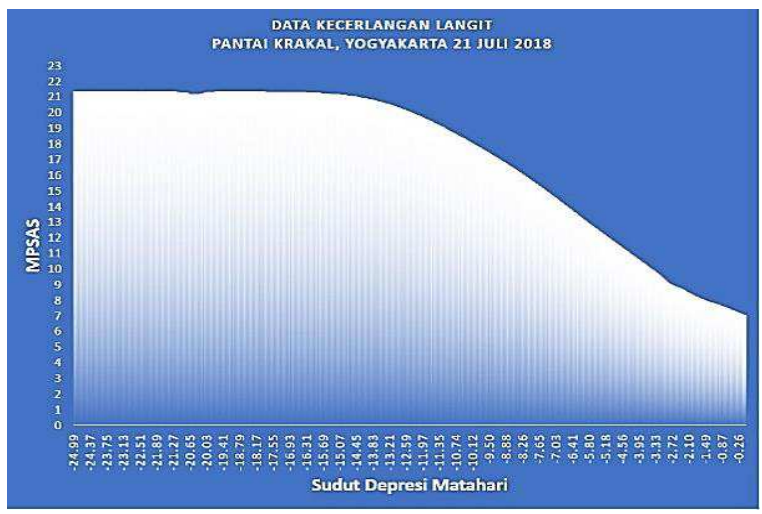

Figure 2. Night sky brightness observation data in Krakal beach, Yogyakarta, July, 212018

Figure 2 shows the nightsky brightness graphic in Pantai Krakal, Yogyakarta per 3 seconds. The $\mathrm{Y}$ axis shows the night sky brightness in the magnitudes per arc second square (MPSAS) unit while the $\mathrm{X}$ axis shows the Solar elevation angle. The higher the number of MPSAS, the darker the sky observed. Meanwhile, the lower the number of MPSAS, the brighter the sky observed. From the graphic we can see that there is a change in brightness in line with the rising of the sun. This means that the higher the sun, the brighter the sky. The dawn is where the sky is started to get brighter, so in order to determine the coming of dawn, the graphic needs to be observed to see where in the local time and the solar elevation when the chart started to see a continuous dip, representing of the coming of the dawn.

To determine the coming of the dawn represented by the turning point in the data or the graphic, the processing of the data was done using several methods, which is solver method, polynomial 5 degree method, and moving average method. The result of these methods was presented in the Table 2 .

Table 2. The Result of Observation and Data Processing

\begin{tabular}{|c|c|c|c|c|c|c|c|}
\hline \multicolumn{2}{|c|}{$\begin{array}{l}\text { Location and } \\
\text { Date of } \\
\text { observation }\end{array}$} & $\begin{array}{l}\text { Solv } \\
\text { er }\end{array}$ & $\begin{array}{l}\text { Pol } \\
5\end{array}$ & $\begin{array}{l}M A \\
3\end{array}$ & $\begin{array}{l}M A \\
5\end{array}$ & $\begin{array}{l}M A \\
7\end{array}$ & $\begin{array}{l}\text { Aver } \\
\text { age }\end{array}$ \\
\hline \multirow[t]{2}{*}{ Depok } & $\begin{array}{l}05 / 11 / \\
2018\end{array}$ & $\begin{array}{l}- \\
14.2 \\
9^{\circ} \\
\end{array}$ & $\begin{array}{l}- \\
17.6 \\
3^{\circ}\end{array}$ & $\begin{array}{l}- \\
11.8 \\
1^{\circ} \\
\end{array}$ & $\begin{array}{l}- \\
12.8 \\
4^{\circ} \\
\end{array}$ & $\begin{array}{l}- \\
13.2 \\
2^{\circ}\end{array}$ & $\begin{array}{l}- \\
13.96 \\
\circ\end{array}$ \\
\hline & $\begin{array}{l}05 / 13 / \\
2018\end{array}$ & $\begin{array}{l}- \\
14.8 \\
7^{\circ} \\
\end{array}$ & $\begin{array}{l} \\
16.8 \\
3^{\circ} \\
\end{array}$ & $\begin{array}{l}- \\
11.2 \\
1^{\circ} \\
\end{array}$ & $\begin{array}{l}- \\
13.1 \\
7^{\circ} \\
\end{array}$ & $\begin{array}{l} \\
13.2 \\
5^{\circ} \\
\end{array}$ & $\begin{array}{l}- \\
13.87 \\
\end{array}$ \\
\hline \multirow[t]{2}{*}{\begin{tabular}{|c}
\multicolumn{1}{c}{ Y } \\
ogyaka \\
rta
\end{tabular}} & $\begin{array}{l}07 / 21 / \\
2018\end{array}$ & $\begin{array}{l}- \\
18.3 \\
5^{\circ}\end{array}$ & $\begin{array}{l}- \\
18.0 \\
3^{\circ}\end{array}$ & $\begin{array}{l}- \\
15.0 \\
8^{\circ} \\
\end{array}$ & $\begin{array}{l}- \\
15.9 \\
6^{\circ} \\
\end{array}$ & $\begin{array}{l}- \\
15.9 \\
6^{\circ} \\
\end{array}$ & $\begin{array}{l}- \\
16.68 \\
\circ\end{array}$ \\
\hline & $\begin{array}{l}07 / 22 / \\
2018\end{array}$ & $\begin{array}{l}- \\
17.8 \\
1^{\circ}\end{array}$ & $\begin{array}{l}- \\
17.3 \\
1^{\circ}\end{array}$ & $\begin{array}{l}- \\
14.1 \\
6^{\circ}\end{array}$ & $\begin{array}{l}- \\
15.0 \\
1^{\circ}\end{array}$ & $\begin{array}{l}- \\
14.9 \\
5^{\circ}\end{array}$ & $\begin{array}{l}- \\
15.85 \\
\circ\end{array}$ \\
\hline \multicolumn{7}{|c|}{ Total average } & $\begin{array}{l}- \\
15.09 \\
\circ\end{array}$ \\
\hline
\end{tabular}


Based on the result of observation and data processin in table 2, it can be obtained that the coming of the dawn happened when the sun is at the elevation of $-15.09^{\circ}$. Compared to the standard used nowadays in Indonesia which is $-20^{\circ}$, there is a difference of $4.91^{\circ}$ or, converted to minute, is around 19 minutes 38.4 seconds. This \pm 19 minutes difference will affect the schedule of Subh prayer that the Indonesian Muslim refer to nowadays. The coming of dawn in the elevation of $-15,09^{\circ}$ shows that the sky is already bright (isfâr). The Prophet SAW said, "Delay Fajr a litte (asfirû bi al-fajr), for it is greater in reward" (Sunan Tirmidzi hadith 142). Wahbah Zuhaili interpret isfâr as starting the Subh prayer after the bright light has spread [28].

The usage of $-20^{\circ}$ solar elevation or equal to 80 minutes before sunrise as the calculation for Subh prayer time in Indonesia, according to Thomas Djamaluddin is quite possible [7]. In certain condition, there is a possibility that dawn came before the solar elevation at $-18^{\circ}$, for example when the thickness of the atmosphere increased or when the air is more dense with dust-like particles so the sunlight was spread by the higher atmospheric layer. This caused the dawn sky phenomenon to be detected even when the solar elevation was less than $-18^{\circ}$ and the sky looks dark. Aisyah said, "The mu'minah women used to attend the Subh prayer with the Prophet and after finishing the prayer they would return to their home and nobody could recognize them because of darkness" (Sunan Ibnu Majah hadith 661). The table 3 shows the Subh prayer time in Jakarta in September 10, 2018 when the sun is at the elevation of $-20^{\circ}$ and $18^{\circ}$.

Table 3. Subh Prayer Time In Jakarta, September, 102018

\begin{tabular}{|l|l|l|l|}
\hline HASIB & $\begin{array}{l}\text { SOLAR } \\
\text { ELEVA } \\
\text { TION }\end{array}$ & $\begin{array}{l}\text { SUBH } \\
\text { PRAYER } \\
\text { TIME (UT+7) }\end{array}$ & $\begin{array}{l}\text { SUBH PRAYER } \\
\text { TIM USING } \\
\text { ELEVATION } \\
\text { OF }- \\
\mathbf{1 5 . 0 9}^{\circ}(\text { UT }+7)\end{array}$ \\
\hline $\begin{array}{l}\text { ISLAMIC } \\
\text { FINDER }\end{array}$ & $-20^{\circ}$ & $04: 32: 00$ & $04: 51: 38.4$ \\
\hline $\begin{array}{l}\text { ACCURAT } \\
\text { E TIME }\end{array}$ & $-18^{\circ}$ & $04: 39: 00$ & $04: 58: 38.4$ \\
\hline KEMENAG & $-20^{\circ}$ & $04: 34: 00$ & $04: 53: 38.4$ \\
\hline
\end{tabular}

From Table 3 we can see that the usage of SQM technology in obersving the dawn sky phenomenon can give a different result in determining the Subh prayer time significantly. The difference of around 19 minutes between the established standard schedule (elevation of $-20^{\circ}$ ) with the result of the observation (elevation of $-15,09^{\circ}$ ) has an implication of the shifting of Subh prayer, imsak time, and fasting time by 8 to 20 minutes.

\section{Conclusion}

The determination of the phenomenon of dawn shadiq in certain angles of sun depression means to facilitate the preparation of the timetable for the morning prayer, justified in the realm of ushul fiqh. According to "qaidah fiqh" that the law can change if there is a change of the place, time and current state. The dawn which is intended as a mark is dawn shadiq or true dawn or astronomical twilight in the form of white light that spreads on the eastern horizon. The appearance of the dawn of the Shadiq set at the angle of depression of $20^{\circ}$ below the 
horizon equivalent to 80 minutes before sunrise and is used as a guideline in compiling the timetable for the morning prayer in Indonesia so far. At the present, using Sky Quality Meter photometer technology, it is found that the phenomenon of dawn on the angle of depression of $20^{\circ}$ below the horizon has not been detected and seen factually. The phenomenon of dawn shadiq can only be detected with Sky Quality Meter at a depression angle of $15^{\circ}$ to $18^{\circ}$ below the horizon equivalent to 60 to 72 minutes before sunrise. This finding shows that the dawn time determined so far is 8 to 20 minutes faster, whereas prayer must be done on time. This research finding also has implications to the shift of dawn time, imsak time, and the time to start fasting 8 to 20 minutes from the time specified in the prayer time schedule.

Acknowledgements. This paper in conjunction with The 2nd International Conference on Law and Justice (ICLJ 2018) in Jakarta, Indonesia.

\section{References}

[1] S. M. F. Al-Bukhairi, Koreksi Awal Waktu Subuh. Malang: Pustaka Qiblati, 2010.

[2] S. Azhari, “Awal Waktu Subuh di Dunia Islam," in Kenferensi Internasional Penyatuan Awal Waktu Salat Subuh Sebuah Upaya Pemenuhan Kriteria Fajar Sidik Yang Objektif Ilmiah, p. 1. 2013.

[3] H. S. Djamari, "Menelaah Kembali Awal Shalat Subuh," Republika, 1999.

[4] R. A. Fatah, "Subh Prayer Time Determined by Goverment," 2010.

[5] F. Wibisono, "Majelis Tarjih Comment About Subh Prayer," 2010.

[6] Saksono, Evaluasi Awal Waktu Subuh dan Isya. Jakarta: UHAMKA Press, 2017.

[7] T. Djamaludin, "Waktu Shubuh Ditinjau secara Astronomi dan Syar'i," Blog, 2010. [Online]. Available: https://tdjamaluddin. wordpress.com/2010/04/15/waktu-shubuh-ditinjau-secara-astronomidan-syari/. [Accessed: 10-Oct-2018].

[8] A. A. Rahman, Qa'idah-Qa'idah Fiqih (Qawa'id al-Fiqhiyyah). Jakarta: Bulan Bintang, 1976.

[9] A. ishak Al-Shatibi, al-Muwafaqat fi Ushul as-Shari'ah. Beirut: Dar al-Kutub al-'Ilmiyah, 2009.

[10] S. Sabiq, Fuqh al-Sunnah, 1st ed. Beirut: Dar Fikr, 1983.

[11] M. Q. Shihab, Tafsir al-Misbah, Pesan, Kesan dan Keserasian Al-Qur'an, 1st ed. Jakarta: Lentera Hati, 2004.

[12] M. A. Al-Sais, Tafsir Ayat al-Ahkam. .

[13] M. A. Al-Shabuni, Rawai'ul Bayan Tafsir Aayat al-Ahkam min al-Qur'an. Dar Fikr.

[14] I. Katsir, Tafsir al-Quran al-Adhim. Beirut: Dar Fikr, 1992.

[15] I. H. Al-Asqalany, Bulugh al-Maram min Adillat al-Ahkam. Beirut: Dar Fikr, 1989.

[16] A. Hassan, Tarjamah Bulughul Maram. Bandung: Cv. Penerbit Diponegoro, 2002.

[17] National Weather Service, "Definition of Twilight", https://www. weather.gov/fsd/twilight.

[18] A. Rachim, Ilmu Falak. Yogyakarta: Liberty, 1983.

[19] Ahmad Islamy Jamil, "Ulama: Waktu Shalat Subuh di Indonesia Perlu Dikoreksi | Republika Online," Republika, 2017. [Online]. Available: https://www.republika.co.id/berita/dunia-islam/islamnusantara/17/08/21/ov1c37361-ulama-waktu-shalat-subuh-di-indonesia-perlu-dikoreksi. [Accessed: 10-Oct-2018].

[20] M. A. Ubé, N. F. Ortin, S. T. Urcotte, B. G. Arcía, and A. M. Ancilla, "Evaluation of the Sky Brightness at Two Argentinian Astronomical Sites," pp. 1068-1077, 2014.

[21] C. W. So, C. S. J. Pun, and C. F. T. Wong, "Effects of cloud amount on the night sky brightness," no. xxx, p. 2012, 2012.

[22] C. Shing, J. Pun, C. Wing, W. Y. Leung, and C. F. Wong, "Journal of Quantitative Spectroscopy \& Radiative Transfer Contributions of artificial lighting sources on light pollution in 
Hong Kong measured through a night sky brightness monitoring network," J. Quant. Spectrosc. Radiat. Transf., vol. 139, pp. 90-108, 2014.

[23] N. N. Shariff, Z. S. Hamidi, and M. S. Faid, “The Impact of Light Pollution on Islamic New Moon ( hilal ) Observation," Int. J. Sustain. Light., vol. 19, no. September, pp. 10-14, 2017.

[24] P. Cinzano and F. Falchi, "The propagation of light pollution in the atmosphere," vol. 3357, no. April 2018, pp. 3337-3357, 2012.

[25] M. Kocifaj, T. Posch, and H. A. S. Lamphar, "On the relation between zenith sky brightness and horizontal illuminance 1 I N T RO D U C T I O N,” vol. 2901, no. April 2018, pp. 2895-2901, 2015.

[26] A. Hasanzadeh, "Study of Danjon limit in moon crescent sighting," Astrophys. Space Sci., vol. 339 , no. 2, pp. 211-221, 2012.

[27] D. Gil, M. Honarmand, J. Pascual, E. Pérez-Mena, and C. Macías Garcia, "Birds living near airports advance their dawn chorus and reduce overlap with aircraft noise," Behav. Ecol., 2015.

[28] W. Al-Zuhaily, Al-Figh al-Islamy wa Adillatuh, 1st ed. Suria: Dar Fikr, 1985. 